\title{
THE IMPORTANCE OF ESTABLISHMENT AND DEVELOPMENT OF TOURISTIC COOPERATIVES IN THE ECONOMY OF RURAL AREAS OF SERBIA
}

\author{
Milena Laban ${ }^{1}$, Milena Janković2 ${ }^{2}$ Đorđe Stojanović ${ }^{3}$ \\ *Corresponding author E-mail: m.zlatkovic86@gmail.com
}

A R T I C L E I N F O
Original Article
Received: 21 May 2021
Accepted: 23 August 2021
doi:10.5937/ekoPolj2103713L
UDC 330+911.373:[338.482:06
(497.11)

Keywords:

tourism development, touristic cooperatives, cooperatives in Serbia, rural areas

JEL: Z320, L83, J54

\begin{abstract}
A B S T R A C T
Rural tourism in Serbia and its development has positive effects on all aspects of rural development, both economic and social. The aim of this paperwork is to investigate the importance that touristic cooperatives in rural areas of Serbia, although relatively new in this area, have and can have on the overall development of rural areas. For the purpose of the research, an interview was conducted with the directors of the existing tourist cooperatives in Serbia. Based on the obtained data, it was determined that this form of cooperative association is necessary, not only because of the development of tourism in the countryside, but above all because of the survival of the Serbian village. The obtained data on the problems and limiting factors that cooperative members face in business can be a further basis for future research on the topic of rural development through the establishment and strengthening of tourist cooperatives.
\end{abstract}

(C) 2021 EA. All rights reserved.

\section{Introduction}

Tourism has proven to be a tool for economic diversification and a major employment engine with a multiplier effect on other sectors that contribute to rural development. Tourism in rural areas can particularly benefit traditionally disadvantaged groups such as women - who make up $54 \%$ of the workforce in the tourism sector compared to

1 Milena Laban, PhD Candidate, Faculty of Hotel Management and Tourism in Vrnjačka Banja, University of Kragujevac, Vojvođanska bb, 36210 Vrnjačka Banja, Serbia, Phone: +381645841901, E-mail: m.zlatkovic86@gmail.com, ORCID ID (https://orcid.org/00000001-7017-4514)

2 Milena Janković, Director of Tourist Organization of Ražanj, Strahinje Simonovića 6, 37215 Ražanj, Serbia, Phone: +381604451858, E-mail: milenajankovic986@gmail.com, ORCID ID (https://orcid.org/0000-0003-2406-4343)

3 Đorđe Stojanović, PhD., Senior Lecturer on Subjects in the Field of Restaurant Management, Academy of Vocational Studies, Department of Hotel Management, Kneza Višeslava 70, 11000 Belgrade, Serbia, Phone: +381641500318, E-mail: djordje.stojanovic@,vhs.edu.rs, ORCID ID (https://orcid.org/0000-0001-9771-3389) 
$39 \%$ for the whole economy - youth and indigenous people. Tourism is also an easy access sector for micro and small enterprises and for the self-employed, who make up a significant part of the tourism sector and community level entrepreneurship in general.

Rural areas face increasing demographic challenges, particularly depopulation, lower income levels, a digital divide, decline in traditional economic activities and lack of economic diversity as well as scarce infrastructure, services and transport connectivity. Rural youth are one of the most vulnerable groups due to the lack of gainful employment and entrepreneurial opportunities in agriculture and related rural economic activities (UNWTO, 2020). Rural tourism attracts new residents, tourists, and entrepreneurs, and, thus, it is considered to be the instrument of revitalization and development of the life and work in rural areas (Findlay, Short, \& Stockdale, 2000). Any form of tourism that showcases the rural life, art, culture and heritage at rural locations, thereby benefiting the local community economically and socially as well as enabling interaction between the tourists and the locals for a more enriching tourism experience can be termed as rural tourism. Rural tourism is essentially an activity which takes place in the countryside. It is multi-faceted and may entail farm/agricultural tourism, cultural tourism, nature tourism, adventure tourism, and eco-tourism. As against conventional tourism, rural tourism has certain typical characteristics like; it is an experience oriented, the locations are sparsely populated, it is predominantly in the natural environment, it meshes with seasonality and local events and is based on preservation of culture, heritage and traditions. Rural tourism has many potential benefits for rural areas (Frederick, 1992).

Rural tourism can be an important source of jobs for local communities. Tourism can be an important force for developing disadvantaged rural areas. In particular, rural communities with few other options for development may perceive that tourism represents a panacea for growth (Aref et al. 2009; Grbić \& Jovanović 2020). Cooperatives are a common organizational form in several large economic, trade and service sectors (Agroinfo, 2020).

Community cooperatives illustrate the primmary benefit of community-driven enterprises; they offer creative solutions to community development issues while maintaining some level of community ownership and control. The activities of cooperatives in rural areas are generally for improving and developing the agricultural sector. At the same time, cooperatives have a flexible structure for dealing with public concern and adapting to changing conditions (Inan, Hurma, 2016) With the development of various forms of modern cooperatives in almost all areas of activity, the cooperative movement in the countries of developed market economies during the 20th century managed to impose itself as a significant autonomous force of the so-called "third sector" in solving some global problems, as well as in achieving more social justice.

The aim of this paper is to examine the potential impact and importance that tourism cooperatives in rural areas in Serbia could have, both on the development of tourism in these areas and on the entire rural economy, as well as to gain a better insight into stimulating and limiting factors that affect their work and future development, in order to eliminate these negative development factors in the future. 


\section{Theoretical background}

According to Njegovan (2016), in the simplest terms, rural tourism can be defined as tourism that takes place in the village. Rural tourism includes relaxation in the rural environment, communication with the hosts, consuming healthy local food, as well as getting acquainted with agricultural activities (Štetić, 2009). Serbia has very favorable conditions for the development of this type of tourism, primarily due to the preserved nature, mild climate, clean air, unpolluted rivers and lakes, as well as rich flora and fauna. The development of this type of tourism greatly contributes to the overall wellbeing of the country, as it enables economic activity to the rural population, which in recent decades has massively migrated to cities, leading to rural extinction, declining domestic agricultural products, urban population growth and thus higher unemployment, as well as numerous other consequences.

Rural tourism in many countries, especially in developing countries, is a mean (Ashley, 2000):

- To achieve macroeconomic growth, especially as a means of generating income from abroad;

- To achieve competitiveness and return on investment of both public and private sectors (tourism is a commercial activity in which business activities are aimed at product development for profit);

- To encourage the conservation process (many conservators see tourism as a form of sustainable use of resources - natural and cultural); and

- For the socio-economic development of the rural population, and as such represents an important component of rural development.

In addition to general, the development of tourism in rural areas can produce a number of positive economic and non-economic effects for agritourism farms themselves. The farms employ a larger number of household members, sell home-made products (embroidery, knitting, folk costumes, handicrafts, etc.), nurture traditions and preserve customs and old forgotten crafts, create opportunities for the return of the population to rural areas and more (Boskovic, 2012).

The accommodation and food sector is closely linked to the development of the tourism economy and makes a considerable contribution to economic growth, employment, enterprise demography and to development in rural, peripheral or less developed areas. Measuring the value of accommodation and food service activities, both in current and constant prices, is therefore particularly important for countries with significant tourism activity. The sector also serves local clients and business customers. (OECD, 2014)

The key products of rural tourism include:

- Agritourism and rural tourism - developed in western and eastern Serbia (Vujko, 2017);

- Ethno-rural tourism, i.e. characteristics of the rural area (culture, history); 
- Eco-rural tourism - developed in Western European countries, refers to the protection of natural resources (Vidović, 2018),

- Combined forms of rural tourism - refer to events, manifestations, recreation and outdoor recreation.

The cooperative sector has been identified by many international organizations, such as the United Nations (UN), the International Labour Organization (ILO), the Food and Agriculture Organization of the UN (FAO) and others, as a suitable sector for stimulating national income growth, employment growth, fuller use of production capacities, as well as poverty reduction. (Victoria logistic, 2020)

Cooperatives in the most developed European countries have a tradition of over 150 years (Zakić, 2018). The primary goal of every cooperative is to meet the needs of its members. They can be an ideal model for uniting different entities in tourism, and some of their advantages for the development of rural tourism would be the following:

- They enable the association and joint action of various entities, for example, individuals such as private landlords and crafts in the field of catering and tourism, with legal entities engaged in tourism services.

- Within the cooperative, each member retains the autonomy of its activities, and has equal voting rights, regardless of the amount invested.

- The cooperative can create an integral and sustainable tourist product composed of elements for which the members of the cooperative are responsible.

- Association in a cooperative gives the possibility of more efficient investment in marketing, because the entire cooperative is promoted, and not each of its members separately.

- Community care as one of the characteristics of cooperatives has a special significance for rural areas and social sustainability (socially beneficial action) (Đurkin Badurina J, 2018; Milojević et al., 2020).

According to the Law on Cooperatives in the Republic of Serbia, a cooperative is a legal entity, which is a special form of organizing individuals who operate their economic, social, cultural and other interests by operating on cooperative principles and who manage and control the cooperative's business. (Zakic, 2018; Bakić, 2020). The cooperative enjoys special protection of the Republic of Serbia, the autonomous province and the unit of local self-government in performing its predominant activities. A cooperative can be founded by at least five business-capable individuals. The smallest number of founders of a cooperative cannot be persons living in a joint household with the founder. Founders and cooperatives may be domestic and foreign natural persons in accordance with the law. The cooperative is managed by cooperative members. In the management of the cooperative, the cooperative members have an equal right to vote on the principle of "one cooperative member - one vote" in the cooperative assembly. 
Today, over 800 million cooperative members in the world are organized into over 750.000 cooperatives. Cooperatives may be established as agricultural or agricultural, housing, consumer, craft, labour, student-youth, social, health, as well as other types of cooperatives for performing production, trade in goods, services and other activities in accordance with this law. In the group of cooperatives with the largest turnover, most are cooperatives in the field of financial services, insurance and trade.

According to the data of the International Cooperative Union, today there are 3 million cooperatives in the world, in which more than $12 \%$ of the total world population has its membership. Cooperatives in the world employ about 280 million people, which is $10 \%$ of the total number of employees in the world. The amount of total turnover of cooperatives is not known, but the importance of the cooperative sector is evidenced by the fact that the 300 largest cooperatives in the world have a turnover of 2.1 trillion USD per year.

Inter-cooperative connection for the purpose of joint appearance on the market in our area is still in its infancy, despite the long tradition of cooperatives. The possibility of forming complex cooperatives, which was first foreseen by the Law on Cooperatives from 2015, opens perspectives for cooperatives and cooperative members to significantly improve their market positions through this form of connection. The development of inter-cooperative cooperation and connections is one of the fastest ways to improve the market position and competitiveness of cooperatives and cooperative members, which is why the Cooperative Union of Vojvodina supports cooperatives to develop their activities in this direction.

To illustrate, some typical examples are given: In the United States, large energy companies are organized as cooperatives. In the UK, the largest travel agencies are cooperatives. In Germany, every fourth inhabitant is a cooperative member. In France, there are 700,000 employees in 21,000 cooperatives. Credit Agricole is one of the largest financial organizations - cooperatives. Two million Norwegians are co-operatives, organized into 4,000 cooperatives, with a turnover of around $€ 15$ billion a year in trade and services. In Croatia, there are about 700 agricultural cooperatives that participate in the total agricultural production with 15-20\% (Agroinfo, 2020)

One of the examples of the application of the cooperative model of organization for the development of rural tourism are diffuse hotels (Đurkin Badurina J. 2018). Diffuse hotels as an innovative form of accommodation intended to unite buildings of different owners for the purpose of providing accommodation services, usually in rural areas and in buildings of historical significance, were created in Italy in response to the depopulation of rural areas. The idea is that diffuse hotels are not "built", but use existing facilities, scattered in several locations within (mostly rural) settlements and have a common reception, catering facilities and other services ("Dall" Ara, 2010.) In Vojvodina, in the past two years, the first complex cooperatives in the field of fruit and vegetables were founded, and already in the first years of their work, they achieved economic effects, which they would not have achieved without association. 
Agriculture, fisheries, banking, insurance, consumption, housing, energy, tourism and health are just some of the areas in which cooperative ideas and principles, in modern conditions, find their application. Today, all forms of cooperatives can be classified into 3 sectors and 16 subsectors (Zakić, Z., 2001):

-Primary sector for food production, which includes three subsectors: agriculture, fisheries and forestry;

-Secondary industrial sector with two subsectors: small and medium cooperative industry and crafts, and

-Tertiary sector (service sector), which covers eleven subsectors: banking, credit unions and insurance (these three make up the financial subsector), consumption, independent retail trade with wholesale, housing, health, social protection, transport, utilities and other activities that belong to unspecified sectors, where, for example, multifunctional, educational, publishing, tourism and other types of cooperatives can be established.

According to the official data of the International Cooperative Union, the largest number of cooperatives in Europe is located in the tertiary, (service) sector. This conclusion was made on the basis of the total number of cooperatives, the number of individual members, as well as the number of employees. The fact that in the countries of the European Union the membership in cooperatives covers over $22 \%$ of the total population, testifies to how important the cooperative sector is as a lever of development. (Victoria logistic, 2020)

About 750,000 cooperatives operate worldwide and have a membership of about a billion people. When it comes to Serbia, 2,124 cooperatives are registered in it (of which 67.1 percent are agricultural), and 123,000 citizens are members of some of the cooperatives. From 2017 to mid-2020, about 720 new cooperatives were established. The importance of cooperative organization has been especially recognized by the EU countries, which have solved numerous problems with the development of cooperatives, primarily those of a social and economic nature. It is estimated that about three billion people are connected, in various ways, with the work of cooperatives. Cooperatives provide more than 100 million jobs worldwide, which is $20 \%$ more than multinational corporations. (Agroinfo, 2020).

The number of rural tourism cooperatives is rapidly increasing worldwide. Through tourism cooperatives, rural populations can generate important and complementary income. For example, agri-tourism cooperatives in Italy emphasize home-made and locally produced foods for tourists that seek a specifically rural or farm experience. Through tourism cooperatives, members may also increase their say in the overall nature, extent, speed and other modalities of tourism development in their area. (International Labour Office, 2011)

In Serbia, the development of tourist cooperatives is still in its infancy. Currently, according to business data from the Business Registers Agency, there are only four cooperatives in the territory of the Republic of Serbia that deal with the development 
of tourism in rural areas of Serbia. These are: Eco-tourist cooperative in Zaovine, the Vineyard-cellar-tourist cooperative in Erdevik, the Agricultural-touristic cooperative from Aleksandrovac and the Tourist-social cooperative from Vrnjačka Banja. There were two other cooperatives of this type: Agritouristic cooperative from Dimitrovgrad, which is in liquidation, and Agricultural-production, touristic cooperative from Nova Varoš. Both of these companies have been deleted from the Register and have not existed since 2017, that is 2011.

\section{Research methodology}

According to (Đoković F. et al. 2007) the area of research is personal opinion that cooperatives' general managers may have on how these touristic cooperatives (active ones) would revitalize tourism through the cooperative business and what positive impacts would tourism have on rural areas. For the research purpose of the current development of tourist cooperatives, their role and importance in rural areas of Serbia, the semi-structured interview method was used (Ayres 2008). Pre-formulated but open questions were asked. The interview was conducted in May, by e-mail and telephone with the directors whose cooperatives are officially registered in the Business Registers Agency. The following hypotheses were set:

H1 - increase of accommodation capacities for receiving tourists,

H2- village renewal and return of young people through job opportunities,

$\mathrm{H} 3$ - increase in demand in the tourism market for rural tourism.

Questions and answers were collected, processed and presented in tables, for each of the cooperatives. Touristic cooperatives in tables are presented as numbers (1-4).

\section{Results \& Discusion}

Table 1. showed the following: out of the total number of active cooperatives on the territory of the Republic of Serbia, two cooperatives were formed this year. Based on their answers, one of them plans to start business activities in the second half of the year, while the other newly formed cooperative achieved good results in business, and in the socio-economic development of the place where it is founded, not as a cooperative, but in terms of individual entrepreneurs, who have decided to cooperate this year and raise their business to a higher level. The other two cooperatives, which have existed before, are currently in the dormant phase, (do not generate turnover). The reasons for that, as it was learned in the conversation with them, are internal, problems with the administration of certain cooperative members, as well as insufficient motivation of cooperative members to associate. As the result of all above mentioned, it can be concluded that tourist cooperatives in Serbia are still in their infancy, so their impact on the development of rural tourism and the rural economy can only be discussed through a projection, in the future. 
Table 1. Work, turnover, predominant activity and focus of the cooperative

\begin{tabular}{|c|c|c|c|c|c|c|}
\hline Coops. & $\begin{array}{c}\text { Date of } \\
\text { founation }\end{array}$ & $\begin{array}{l}\text { Cooperative } \\
\text { Orientacion }\end{array}$ & $\begin{array}{l}\text { Fokus of the } \\
\text { cooperative }\end{array}$ & $\begin{array}{l}\text { Market } \\
\text { activity? } \\
\text { Yes/ No }\end{array}$ & $\begin{array}{l}\text { Generating } \\
\text { turnover? } \\
\text { Yes/ No }\end{array}$ & $\begin{array}{l}\text { Business } \\
\text { results are } \\
\text { positive? } \\
\text { Yes } / \text { No }\end{array}$ \\
\hline \multirow[b]{2}{*}{1.} & \multirow[b]{2}{*}{ 13.06.2018 } & \multirow{2}{*}{$\begin{array}{l}\text {-Agriculture } \\
\text {-Tourism } \\
\text {-Ecology } \\
\end{array}$} & \multirow{2}{*}{$\begin{array}{l}\text {-Accomod. } \\
\text {-Cultural } \\
\text { inheritage }\end{array}$} & No & No & No \\
\hline & & & & \multicolumn{3}{|c|}{ Currently at a standstill with business } \\
\hline \multirow[b]{2}{*}{2.} & \multirow[b]{2}{*}{ 24.11.2008 } & & \multirow{2}{*}{$\begin{array}{l}\text {-Accomod. } \\
\text {-Gastronomy } \\
\text { - Return of } \\
\text { youth to rural } \\
\text { areas }\end{array}$} & No & No & No \\
\hline & & $\begin{array}{l}\text {-Agriculture } \\
\text {-Wine tourism }\end{array}$ & & \multicolumn{3}{|c|}{$\begin{array}{l}\text { Standstill due to internal problems, } \\
\text { starts business in the second half of the } \\
\text { year }\end{array}$} \\
\hline \multirow[b]{2}{*}{3.} & \multirow[b]{2}{*}{18.03 .2021} & & -Accomod. & No & No & No \\
\hline & & -Tourism & $\begin{array}{l}\text {-Gastronomy } \\
\text {-Return of } \\
\text { youth to rural } \\
\text { areas }\end{array}$ & \multicolumn{3}{|c|}{ Newly formed cooperative } \\
\hline \multirow[b]{2}{*}{ 4.* } & \multirow[b]{2}{*}{ 13.05.2021 } & & -Accomod. & Yes & Yes & Yes \\
\hline & & $\begin{array}{c}\text {-Tourism } \\
\text {-Ecology } \\
\text {-Social aspect }\end{array}$ & $\begin{array}{c}\text {-Gastronomy } \\
\text {-Cultural } \\
\text { inheritage } \\
\text {-Connection } \\
\text { and } \\
\text { cooperation } \\
\text { with } \\
\text { institutions } \\
\text { - Return of } \\
\text { young people } \\
\text { to rural areas } \\
* *\end{array}$ & \multicolumn{3}{|c|}{$\begin{array}{l}\text { * Very young, has turnover and acheves } \\
\text { business results not as a cooperative, } \\
\text { but as individual economic entities but } \\
\text { now it organizes its work into a higher } \\
\text { form of cooperative association. } \\
\text { ** Purchase, promotion and protection } \\
\text { of certain products from the mountain, } \\
\text { purchase od teas, medical herbs, } \\
\text { mushrooms, fruit, vegetables, cheese, } \\
\text { cream, meat, and meat products and } \\
\text { their placement through restorants. }\end{array}$} \\
\hline
\end{tabular}

\section{Source: Author's research}

All tourist cooperatives focus mostly on tourism in terms of accommodation (100\%), then gastronomy $(75 \%)$, the return of young people to the countryside $(75 \%)$, cultural inheritage (only one of them), and connecting with other relevant entities (25\%). In addition to the classic tourism in their activities they are oriented to agriculture, ecology, while as many as $75 \%$ of them are oriented to the aspect of the return of young people to the countryside. Thanks to the development of the cooperative, twelve young people have already been returned to the mountain of Goč and their livelihoods have been provided through good salaries, and based on that, previously set hypotheses can be confirmed - H1- increase of accommodation capacities for receiving tourists and $\mathrm{H} 2$ - village renewal and return of young people through job opportunities. 
Table 2. Positive and negative factors that enable or prevent the work of the cooperative

\begin{tabular}{|c|c|c|}
\hline Cooperative & Positive factors & Negative factors \\
\hline 1. & - Ecologically preserved environment & $\begin{array}{l}\text { - Extensive and complicated administration } \\
\text { - Impossibility of association } \\
\text { - Difficulcy of finding a partner and lack of } \\
\text { interest in cooperation } \\
\text { - Poor communication with partners } \\
\text { - Insufficient coop. with tour. institutions } \\
\text { - Lack of economic resources } \\
\text { - Lack of traffic infrastructure } \\
\text { - Outflow of population } \\
\text { - Lack of support from public institutions } \\
\text { - Pandemic outbreak }\end{array}$ \\
\hline 2. & $\begin{array}{l}\text { - Interest of the local community in } \\
\text { cooperation } \\
\text { - Assistance and support from state } \\
\text { institutions } \\
\text { - Ecologically preserved environment } \\
\text { - Good traffic connections with larger } \\
\text { cities } \\
\text { - Great tourist potential of the area } \\
\text { - Pandemic outbreak }\end{array}$ & - Outflow of population \\
\hline 3. & $\begin{array}{l}\text { - Interest of the local community in } \\
\text { cooperation }\end{array}$ & $\begin{array}{l}\text { - Insufficient coop. with tour. institutions } \\
\text { - Lack of economic resources }\end{array}$ \\
\hline 4. & $\begin{array}{c}\text { - Ecologically preserved environment } \\
\text { - Good traffic connections with larger } \\
\text { cities (municipalities, but not villages) } \\
\text { - Great tourist potential of the area } \\
\text { - Higher influx of tourists and higher } \\
\text { need for products }\end{array}$ & $\begin{array}{c}\text { - Impossibility of association } \\
\text { - Insufficient coop. with tour. institutions } \\
\text { - Lack of economic resources } \\
\text { - Lack of traffic infrastructure } \\
\text { - Outflow of population } \\
\text { - Lack of support from public institutions } \\
\text { - Pandemic outbreak }\end{array}$ \\
\hline
\end{tabular}

Source: Author's research

Based on the answers given in Table 2, it can be seen that the importance of cooperative development is largely recognized by the local community $(50 \%)$, that cooperatives are situated in an environmentally friendly environment (75\%), and that partly there are good traffic connections, but the infrastructure in some areas is quite poor $(50 \%)$, the outflow of population is huge $(75 \%)$ and cooperatives do not have enough material funds for work and development (75\%). Factors that most often aggravate development, and which cooperatives encounter in practice, are lack of support from institutions http://ea.bg.ac.rs 
(75\%), outflow of population (75\%), lack of infrastructure, impossibility of association $(50 \%)$, difficulcies in finding partners, poor communication with business partners. It is interesting that the outbreak of a pandemic is a factor that helps development in some cooperatives, while in some it has been a problem in the work so far.

Table 3. Type of support, impact and level of tourist development of the place (village)

\begin{tabular}{|c|c|c|c|}
\hline \multicolumn{4}{|c|}{ In your personal opinion, is the place where your cooperative operates touristically developed? } \\
\hline \begin{tabular}{|c|}
1. \\
\end{tabular} & 2. & 3. & 4. \\
\hline $\begin{array}{l}\text { Yes, it is already well } \\
\text { developed in terms of } \\
\text { tourism }\end{array}$ & $\begin{array}{l}\text { It is not developed for } \\
\text { tourism, but it has a huge } \\
\text { potential for development }\end{array}$ & $\begin{array}{c}\text { It is not developed } \\
\text { for tourism, but it has } \\
\text { a huge potential for } \\
\text { development }\end{array}$ & $\begin{array}{l}\text { It is not developed for } \\
\text { tourism, but it has a huge } \\
\text { potential for development }\end{array}$ \\
\hline \multicolumn{4}{|c|}{ What hinders the development of tourism (as a whole) in the place (area) where you do business? } \\
\hline \begin{tabular}{c|c|}
1. & \\
\end{tabular} & \begin{tabular}{|c|}
2. \\
\end{tabular} & 3. & 4. \\
\hline $\begin{array}{c}\text { - Lack of accommod. } \\
\text { capacity } \\
\text { - Poor infrastructure } \\
\text { and traffic connections } \\
\text { - Lack of support from } \\
\text { pub. institutions }\end{array}$ & $\begin{array}{c}\text { - Lack of accommodation } \\
\text { capacity } \\
\text { - Unrecognizability } \\
\text { in the tourist market } \\
\text { (insufficient promotion) }\end{array}$ & $\begin{array}{c}\text { - Lack of } \\
\text { accommodation } \\
\text { capacity } \\
\text { - Lack of support from } \\
\text { public institutions }\end{array}$ & $\begin{array}{l}\text { - Unrecognizability } \\
\text { in the tourist market } \\
\text { (insufficient promotion) }\end{array}$ \\
\hline \multicolumn{4}{|c|}{$\begin{array}{l}\text { Do you think that the existence of your cooperative has a significant impact (economic, social, } \\
\text { tourist, environmental...) on the local community? }\end{array}$} \\
\hline \begin{tabular}{|c|}
1. \\
\end{tabular} & \begin{tabular}{|c|}
2. \\
\end{tabular} & 3. & 4. \\
\hline It could have & No & Yes, to a large extent & Yes, to a large extent \\
\hline \multicolumn{4}{|c|}{ Is the support of institutions important to you? } \\
\hline 1. & 2. & 3. & 4. \\
\hline $\begin{array}{l}\text { It is necessary to a } \\
\text { lesser extent }\end{array}$ & It is crucial & It is crucial & It is crucial \\
\hline \multicolumn{4}{|c|}{ What kind of support do you need? } \\
\hline 1. & 2. & 3. & 4. \\
\hline $\begin{array}{l}\text { Institutional } \\
\text { (Local education and } \\
\text { informing } \\
\text { community about the } \\
\text { importance of coops, } \\
\text { material assistance) } \\
\end{array}$ & $\begin{array}{c}\text { Institutional } \\
\text { (Funds for equipping and } \\
\text { building bungalows and } \\
\text { restaurants) }\end{array}$ & $\begin{array}{c}\text { Institutional } \\
\text { (Credit funds for } \\
\text { building a planned } \\
\text { village with a capacity } \\
\text { of } 30 \text { beds) }\end{array}$ & $\begin{array}{c}\text { Institutional } \\
\text { (Regional and national } \\
\text { connection, necessary } \\
\text { material resources) }\end{array}$ \\
\hline
\end{tabular}

Source: Author's research

All cooperatives $(100 \%)$ have made it clear that institutional (state) assistance is crucial or to a lesser extent necessary for the further development of their business, mostly in material terms (Table 3). There is also a need for additional education of the local community on the importance of the cooperatives $(25 \%)$, as well as connecting cooperatives with institutions on a national and regional level in terms of support. Most of the municipalities 
in which the cooperatives are located are not developed in terms of tourism, although they have the potential to develop (except for the cooperative numer 4, which as a destination, that is, the municipality to which the cooperative belongs, is already well developed). The development of these cooperatives, according to the answers given, could change that. Namely, $50 \%$ of respondents said that touristic cooperatives have a large overall impact on the rural economy, one answered that it could have a large impact in the future (currently the business is dormant), while only one respondent stated that it has no impact at present ( still no turnover, newly formed cooperative).

Table 4. Vision of future business and additional notes

\begin{tabular}{|c|c|}
\hline \multicolumn{2}{|r|}{ Describe the vision of your tourist cooperative's business in the future } \\
\hline 1. & $\begin{array}{l}\text { To be a center for tourist information (locally), to unite the tourist offer of the } \\
\text { place, to generate income, for accommodation and tourism promotion. }\end{array}$ \\
\hline 2. & $\begin{array}{l}\text { Initiation of work with the construction of accommodation bungalows with } \\
\text { an unconventional restaurant for wine tasting, on two lakes. Development of } \\
\text { rural tourism. The return of young people to the countryside, primarily their } \\
\text { members. }\end{array}$ \\
\hline 3. & $\begin{array}{l}\text { Segments of social contacts, culture and sports. The plan is to build an ethno- } \\
\text { village in the rural area of Serbia }\end{array}$ \\
\hline 4. & $\begin{array}{l}\text { Placing local products from the mountains (two restaurants), zip line, horse } \\
\text { stables, riding on mountain terrains, setting up an amusement park for children } \\
\text { with the aim of employing primarily the local population. Construction of } \\
\text { a trim trail for walks, maybe paragliding, climbing rocks and a town that } \\
\text { spreads on a four acress with all the infrastructure, spa and other facilities. } \\
\text { Establishment of a festival of ecological character (the festival from 25. to } \\
\text { 27. June will have an entertaining character, will contain information about } \\
\text { the offer of the mountain, education and work action with the camp where } \\
\text { participants will be involved in cleaning, with recycling stands), afforestation, } \\
\text { raising awareness of ecology, renewable energy sources. }\end{array}$ \\
\hline \multicolumn{2}{|r|}{ Additional notes } \\
\hline 1. & $\begin{array}{l}\text { Until recently only the elder population lived, but now younger people are } \\
\text { coming and inhabiting the area which means recognizing the potential by } \\
\text { younger people. Until a couple of years ago, the average age was } 65 \text { to } 70 \text {, in a } \\
\text { place with only } 300 \text { to } 400 \text { people. }\end{array}$ \\
\hline 2. & $\begin{array}{l}\text { Depopulation of the village, once lived about } 5,000 \text { people, and now only about } \\
1,000 \text {. For now, the complex is visited only by those who know that it is located } \\
\text { there. }\end{array}$ \\
\hline 3. & No additional notes \\
\hline 4. & $\begin{array}{l}\text { The population finds it difficult to market their products, they do not have } \\
\text { a protected product, the fruit region is exceptional, the fruit is of first-class } \\
\text { quality, the aspiration is to protect the geographical origin, the problem of } \\
\text { transport and traffic. There are no buses or any other form of public transport. }\end{array}$ \\
\hline
\end{tabular}

Source: Author's research 
As it can be seen from Table 4, touristic cooperatives in the places where they are located plan to build accommodation facilities for tourists, in the form of ethno-villages, bungalows and smaller hotels, restaurants and places for tasting food and drinks (wine), as and organizing a number of other additional facilities that would complement the tourist offer of the village, such as organizing events and sports events, entertainment and theme parks, horseback riding, zip-line, marking trim trails for walking and hiking, climbing rocks (adventure tourism). Such an offer would significantly contribute to higher tourist demand and higher attendance of these rural areas, based on which hypothesis H3 is confirmed - an increase in demand in the tourist market for rural tourism. Cooperatives could unite their offer, be a center for informing tourists about the offer of the village, but also about recycling, renewable energy sources, etc. In that way, the problem of depopulation and departure of young people would be solved, and that would have a positive impact on the overall economy of the village.

The biggest problem of rural development, and thus of touristic cooperatives in rural areas of Serbia so far has been the increasing depopulation of villages, the departure of young people from rural areas and the rest of a small number of elderly people. Another problem they face is the lack of support from relevant state institutions, primarily in material terms. The third problem is the insufficiently developed infrastructure and network of traffic roads in rural and mountainous-rural areas of Serbia. Regarding to this, for the first time this year, the Government of the Republic of Serbia developed support through measure 7 (seven). Diversification of agricultural holdings and business development is aimed at creating new employment opportunities in rural areas, and thus reducing dependence on agriculture and improving quality and the availability of basic services and infrastructure. The focus of diversification within the IPARD II program is rural tourism, due to the existence of a long tradition and great potential and the need for further development of the sector. (Ministry of Agriculture, Forestry and Water Management, 2021)

In a public competition for the implementation of the Program to support the development of cooperatives by awarding grants for business improvement and technological development of cooperatives throughout territory of the Republic of Serbia for 2021, announced by the Ministry of Rural Care, it is stated in the third point that the applicants for the competition may be, among others, agricultural or agricultural cooperatives whose registered activity is engaged in rural tourism - accommodation and food services (tourist cooperatives), which have acquired the status of a legal entity by entry in the register kept by the entity responsible for registration (Business Registers Agency), until the announcement of the public competition.

This Program aims to systematically improve the business of cooperatives in agriculture, rural tourism and crafts, increase the number of cooperatives, develop the cooperative system and increase competitiveness in the market, as well as create opportunities for cooperatives to contribute to sustainable development of the local community. (Ministry of Rural Care, 2021) 


\section{Conclusion}

This paperwork confirms the hypotheses about increasing accommodation capacity for receiving tourists, rebuilding villages and returning young people through creating new jobs and increasing demand in the tourism market for rural tourism, and as a result, touristic coorporatives can make important contributions to socioeconomic development of rural areas. At the same time, they play a role in ensuring the growth of the rural welfare. The growing demand for the rural areas may provide an important contribution to the development of tourism in terms of income to the producers in these areas.

The availability of IPARD funds, strengthening social capital and market links, should strengthen rural communities and contribute to their sustainable development in the future. (Ministry of Rural Care, 2021)

Despite all the problems, the population in rural areas increasingly recognizes the importance of establishing and strengthening tourist cooperatives, which, through their work in the future, could be the backbone of the development of very attractive but underdeveloped rural areas in Serbia. „Cooperatives are development tools and should promote both social empowerment and economic goals" (Patrie, 1998, p. 11)

The most effective method of rural development is to increase rapidly the welfare of the people directly or indirectly. The economic benefits of creating cooperatives for the development of rural tourism offer are reflected in the opportunities for cooperation and investment in overcoming the challenges of rural areas through investing the roles that each member brings to the cooperative. In addition, by forming tourism cooperatives, rural areas would get stronger platforms for the development of rural tourism, as well as a good basis for cooperation on projects of local importance, which would positively affect the creation of social capital in the community. (Đurkin Badurina J, 2018)

It is important to ensure support for sustainable rural development and living standards of people dependent on agriculture by strengthening cooperatives and stimulating sustainable ways of production, processing and distribution of food and forming clusters through which farmers will connect, both with each other and with certain scientific institutions. with the aim of more rational use of available natural resources and human resources.

\section{Conflict of interests}

Authors declare no conflict of interest.

\section{References}

1. Bakić, S. (2020). The role of the Central Bank as a participant in the financial derivatives market. Oditor - časopis za menadžment, finansije i pravo, 6(1), 2237. https://doi.org/10.5937/Oditor2001021B 
2. Činjarević M. Pestek A. (2019): The distinctiveness of rural tourism marketing practices: The case study of Bosnia and Herzegovina, Academica turistica Journal, Year 12, No.2 (173), Retrieved from: http://academica.turistica.si/index. $\mathrm{php} / \mathrm{AT}-\mathrm{TIJ} / \mathrm{article} / \mathrm{view} / 195$ (April 23 ${ }^{\text {rd }}, 2021$ )

3. Da bi razvijali seoski turizam ne treba ništa novo izmišljati već samo se potruditi uložiti i srediti lepote Srbije. [In order to develop rural tourism, you don't need to invent anything new, you just have to try to invest and fix beauties of Serbia]. Agroinfo (2020), Retrieved on April 19 th $^{\text {th }} 2021$ from https://www.agroinfo.rs/dabi-razvijali-seoski-turizam-netreba-nisa-novo-izmisljati-vec-samo-se-potruditiuloziti-i-srediti-lepote-srbije-6427

4. Đoković F, Pejanović R, Mojsilović M, Đorđević Boljanović J, Plećić K, (2007): Opportunities to revitalize rural tourism through the operation of agrarian cooperatives 1115-1132, Economics of Agriculture 3/2017, Retrieved from: http://www.ea.bg.ac.rs/index.php/EA/article/view/77 (April 16 ${ }^{\text {th }}, 2021$ )

5. Đurkin Badurina J. (2018). Zadruge kao organizacijski blici održivog razvoja turizma u ruralnim područjima. [Cooperatives as organizational forms suitable for sustainable development of tourism in rural areas], Journal for economical, business and social themes Notitia, Vol 4. No.1, Retrieved from: https://doi. org/10.32676/n.4. (April 15 ${ }^{\text {th }}, 2021$ )

6. F. Aref, Sajrit S. Gill, (2009): Rural tourism development through rural cooperatives, Nature and Science Journal, (68-73), Retrieved from: https://www. researchgate.net/publication/305397865_Rural_tourism_development_through_ rural_cooperatives (May $\left.11^{\text {th }}, 2021\right)$

7. Grbić, M., \& Jovanović, D. (2020). Comparative financial systems: Implications for economic growth. Oditor - časopis za menadžment, finansije i pravo, 6(1), 49-65. https://doi.org/10.5937/Oditor2001046G

8. Hagen H, Schimmel C. (2011, June 30 $\left.{ }^{\text {th }}\right)$ ): Cooperatives for People-centered rural development (3), International Labour Office, Retrieved from: https://www. ilo.org/employment/units/rural-development/WCMS 158998/lang--en/index. $\underline{\mathrm{htm}}$ (April, 20 ${ }^{\text {th }}, 2021$ )

9. Inan C. Hurma H. (2016): The role of cooperative organizations in the development of ecotourism, Conference: Balkan and Near Eastern Journal of Social Sciences - Plovdiv/Bulgaria (8), Retrieved from https://www.researchgate. net/publication/312022221_The_Role_of_Cooperative_Organizations_in_the Development_of_Ecotourism $\left(\right.$ May, $\left.12^{\text {th }}, 2 \overline{0} 21\right)$

10. Marković K. (2007), Agricultural cooperatives in the Republic of Serbia - state and perspectives, Yearbook of scientific papers of the Faculty of Agriculture 2007, vol. 31, No. 1, 114-121, Retrieved from: https://scindeks-clanci.ceon.rs/ data/pdf/0546-8264/2007/0546-82640701114M.pdf (April, 17 ${ }^{\text {th }}, 2021$ )

11. Milojević, I., Mihajlović, M., \& Pantić, N. (2020). Collection and documentation of audit evidence. Oditor - časopis za menadžment, finansije i pravo, 6(2), 77-90. . https://doi.org/10.5937/Oditor2002077M 
12. Milovanović V, Milićević S. (2014). Management of tourist products of Serbia in the function of improving competitiveness on the international tourist market, Tourism International Scientific Conference - TISC, Faculty of Hotel Management and Tourism in Vrnjačka Banja, University of Kragujevac, 41-42, Retrieved from https://www.tisc.rs/proceedings/index.php/hitmc/article/view/139 ( May 12 ${ }^{\text {th }}$, 2021)

13. Ministry of Agriculture, Forestry and Water Management (2021): Measure 7Diversification of agricultural holdings and business development, Directorate for Agrarian Payments, retrieved from http://uap.gov.rs/mera-7-diverzifikacijapoljoprivrednih-gazdinstava-i-razvoj/ (April 19 ${ }^{\text {th }}, 2021$ )

14. Ministry of Economy, Law on Cooperatives in Serbia, (2015), Retrieved from: http://www.priv.rs/Zakoni/10345/Zakon--o-zadrugama.shtml (April 15th, 2021)

15. Ministry of Rural Care, Public competition for the implementation of the Cooperative Development Support Program by awarding grants for business improvement and technological development of Cooperatives on the entire territory of the Republic of Serbia, (2021). Retrieved from: http://www.mbs.gov. rs/doc/konkursi/tekst-javnog-konkursa.pdf (April 19 $9^{\text {th }} 2021$ )

16. Njegovan Z. (2016). Ekonomika turizma i seoskog turizma. [Economics of Tourism and Rural Tourism], Faculty of Agriculture, University of Novi Sad (157), Edition Main Textbook, Retrieved from: http://polj.uns.ac.rs/sites/default/ files/udzbenici/Ekonomikaturizmaiseoskogturizma.pdf (May 12 ${ }^{\text {th }}, 2021$ )

17. OECD/Eurostat (2014), "Accommodation and food service activities", in Eurostat-OECD Methodological Guide for Developing Producer Price Indices for Services: Second Edition, OECD Publishing, Paris. Retrieved from: https:// www.oecd-ilibrary.org/economics/eurostat-oecd-methodological-guide-fordeveloping-producer-price-indices-for-services_9789264220676-en (April 21 ${ }^{\text {st }}$, 2021)

18. Tasić J. (2018). Budući trendovi i pravci razvoja ruralnog turizma u Srbiji i u svetu. [Future trends and directions of rural tourism development in Serbia and in the world], Oditor Magazine, vol. 4, br. 3, (pp. 1-13), Retrieved from: https:// scindeks-clanci.ceon.rs/data/pdf/2217-401X/2018/2217-401X1803007T.pdf (April 19 ${ }^{\text {th }}, 2021$ )

19. UNWTO, (2020). Recommendations on tourism and rural development: A guide to making Tourism an effective tool for rural development, (7-8), Retrieved on April $20^{\text {th }}, 2021$ from https://www.e-unwto.org/doi/book/10.18111/9789284422173

20. Wattles I. (2019). Intervju kao istraživačka metoda - Teorijski aspekti. [Interview as a research method - Theoretical aspects], CIVITAS Magazine, 2019, vol. 9, no. 2, (206), Retrieved from: https://scindeks.ceon.rs/article.aspx?artid=221749581902201W (April, 21 $1^{\text {st }}, 2021$ )

21. Zadruge u svetu. [Cooperatives in the world], Victoria logistic (2020), retrieved from https://www.victorialogistic.rs/poljoprivreda/zadrugarstvo-u-svetu (April 23rd, 2021) 
22. Zakić V, Nikolić M. (2018). Finansijska podrška države zadrugama u Srbiji. [State financial support to cooperatives in Serbia], Repository of the Faculty of Agriculture, Business School, University in Belgrade, (158-174), retrieved from: http://aspace.agrif.bg.ac.rs/handle/123456789/4822 (April 23rd, 2021)

23. Zeuli K, Freshwater D, Markley D, Barkley D. (2004): Cooperatives in rural community development: A new framework analysis, Journal of the Community Development Society Vol. 35 No. 2, Retrieved from: https://www.researchgate.net/ publication/247529062_Cooperatives_in_Rural_Community_Development_A_ New_Framework_for_Analysis (April 19 $\left.{ }^{\bar{t}}, 2021\right)$ 